\title{
Investment Optimization on Container Capacity of Shanghai (China)
}

\author{
Gang Dong \\ School of Economics and Management, Shanghai Maritime University, Shanghai, China
}

\section{Email address:}

gangdong@shmtu.edu.cn

\section{To cite this article:}

Gang Dong. Investment Optimization on Container Capacity of Shanghai (China). International Journal of Economics, Finance and Management Sciences. Vol. 4, No. 4, 2016, pp. 205-210. doi: 10.11648/j.ijefm.20160404.16

Received: July 2, 2016; Accepted: August 1, 2016; Published: August 3, 2016

\begin{abstract}
Over the past few decades, mainland China has reformed restrictions on its port investment in order to meet the huge demand of related infrastructure, especially promulgated the deregulation of foreign investment into container port. Nowadays, port investments have included the state investment, bank loans, self-raised funds, foreign investment and IPO and so on. We focus on investment optimization of container capacity with the basics of the model proposed, putting forth some conclusions and policy recommendations through conducting numerical illustration of the Shanghai case.
\end{abstract}

Keywords: Investment Optimization, Container Capacity, Foreign Investment, Deregulation

\section{Introduction}

As the most important gateways for international trade, the performance of ports is becoming a key determinant of countries' competitiveness. In consideration of a lot of repositioning of empty containers occurs, world container port throughput is more than two and a half times of the container transported globally, increasing by 5.1 percent to 684.4 million TEUs in 2014. Among which, Chinese ports handled more cargo both in terms of metric ton volume and number of TEUs than any other country, the cargo volume was at 12.5 billion tons of cargo in 2014, an increase of 5.8 percent over the previous year. Similarly, the containerized cargo grew by an increase of 6.4 percent to 202 million TEUs. Especially, among the world's 20 leading container ports in 2014, mainland China ports such as Shanghai, Shenzhen, Hong Kong, Ningbo, Guangzhou, Qingdao, Tianjin, Dalian, and Xiamen are on the list.

Over the past few decades, port sector in mainland China has reformed restrictions on its capital source in order to meet the huge demand of port infrastructure, especially promulgated the deregulation of foreign investment. Nowadays, port investments are including the state investment, bank loans, self-raised funds, foreign investment and IPO and so on. We focus on optimization of state-owned capital and foreign investment with the basics of the model proposed, putting forth some conclusions and policy recommendations through conducting numerical illustration of the Shanghai case.

\section{Literature Review}

Since the late 1980s and early 1990s, many countries have gradually adopted port policy reforms. Cullinane et al. [1] found that the transformation of ownership from public to private sector improves economic efficiency, providing some justification for the many programmes in Asian ports which aim to attract private capital into both existing and new facilities. Similarly, Tongzon and Heng [2] calculate that private sector participation in the port industry to some extent can improve port operation efficiency, which will in turn increase port competitiveness. Gong et al. [3] provide a synthesis of the international evidence with respect to the impact of privatization on the efficiency and performance of airports and seaports. In line with other reforming countries around the world, the regulatory reforms of the Spanish port system rested on three key instruments: decentralisation (port autonomy), participation of private sector and introduction of competition [4], [5].

Minimum Efficient Scale (MES) is salient from the perspective of port authorities or governments, because they sometimes determine the port development or expansion based on the port capacity. Allahviranloo and Afandizadeh [6] formulate an investment optimization problem where cargo 
operation, investment costs, cargo-handling capacity, cargo transportation network, and the world maritime fleet constraints are included. Lin et al. [7] propose a simulation model considering various types of container ships and cranes, flexible berth allocation and dynamic crane scheduling. Ioannis et al. [8] take port infrastructure investments into account various uncertainties, which can impact the return of the investment over the project's useful life. Xiao et al. [9] develop an integrated economic model for the analysis of disaster-prevention investments at a "landlord" port, showing that the timing of port investments depends on the probability of disasters. Seo and Park [10] explore a bottom point of the average cost curve in order to suggest an adequate scale for the port industry in Korea, demonstrating that under capacity may be a strong issue in Korean container ports.

In China, many ports have rapidly improved their infrastructure and superstructure following intensive investment through large-scale projects after deregulation of foreign investment. China's tremendous growth momentum enabled many Chinese ports to enjoy record throughput growths, with investments in terminal capacity and operational efficiency, shipping lines might be induced to shift their transshipment activity from the incumbents to these upstarts [11]. Chinese ports now threaten to oust Busan in Korea as the regional hub, but enhanced port competitiveness requires not simply increased port investment but also high quality port service and technology focused port operations [12]. To quantify the characteristics of port regulation modes by using port reform experiences in China, the tariff, port efficiency level, port service demand and social welfare are higher under the decentralization mode [13]. Port infrastructure investment in China also contributes to growth of the regional economies involved [14]. Zhang [15] analyzes the Chinese quasi-landlord port financing model from a contract theory perspective, in which it can be viewed as a double-level principal-agent relationship and two-layer profit distribution contract with three participants.

\section{Deregulation of Foreign Investment in China's Port Sector}

The "interim provisions" of the State Council in 1985 was a symbol of China's port sector opening to foreign capital, marking the beginning of the quasi-privatization process in the country. Thereafter, Nanjing International Container Terminal Company Co., Ltd was established on December 5, 1987, joint investing by Nanjing Port Authority and Encinal Terminals of U.S.A, with total registered capital of 17.1 million USD and the ratio of Sino-foreign share is $61.63 \%: 38.37 \%$, which became the first Sino-foreign container-handing enterprise in mainland China. Subsequently, Tianjin Port and Norway Bugiel Shipping company jointly transformed 250 meters coastline's general cargo terminal into container terminal. Zhangjiagang Win Hanverky Container Terminal Co., Ltd was built on December 1, 1992; joint investing by Zhangjiagang
Port Authority and COSCO Hongkong Pacific Ltd., with total registered capital of 75 million USD and the ratio of Sino-foreign share is 51\%:49\%.

To implement the spirit of Deng Xiaoping's Talks in the South on January 18 to February 21, 1992, marking China's reforms and opening up entering a new stage, Ministry of Transport promulgated the "Instructions about deepening reform, expanding opening up and speeding up the development of traffic" on July 25, 1992. The instructions further encourage foreign investment to build and operate public dock berth, allowing Sino-foreign joint venture to lease terminal and handle loading-unloading business, even permitting wholly foreign-owned enterprise to construct cargo owner's wharf and special purpose channel. Under this circumstance, Shanghai Container Terminal Co., Ltd was set up on August 12, 1993, joint investing by Shanghai Port Container Co., Ltd and Hutchison Port Holdings Limited of Hongkong, with total investment reaching to 6.8 billion USD and the ratio Sino-foreign share is $50 \%: 50 \%$, which was major breakthrough for the investment scale and share held. Yantian International Container Terminals Limited was established on October 5, 1993, joint investing by Shenzhen Yantian Port Group and Hutchison Port Holdings Limited of Hongkong, with registered capital of 2.4 billion HK and the ratio Sino-foreign share is 27\%:73\%, which was the first container terminal joint venture controlled by foreign investor in mainland China.

In order to further expand the openness and utilize foreign investment, especially adapt to the new situation of entry into the WTO, the State Planning Commission, Commission for Economics and Trade, Ministry of Foreign Trade and Economic Department jointly promulgated the new "directory of foreign investment industry" on March 11, 2002. Among which, the construction and operation of the public port facilities were classified as encouraging industry directory to foreign investment, canceling the limitations on the proportion of share ownership. Meanwhile, the "directory of foreign investment industry" issued on December 31, 1997 was abolished, which set up the condition that Chinese party controls the shares. Soon afterwards, the "Port Law" was signed by NPC Standing Committee On June 28, 2003, pointing out that the state will continue to encourage economic organizations and individuals at home and abroad to invest and operate port sector, keeping the greatest degree of opening to foreign and private capital, also stipulating that the legitimate rights and interests of port investor will be protected in accordance with law.

\section{Optimization Model of Container Capacity Investment}

To meet the huge demand of port infrastructure, the detailed arrangements include mere commercialization (which involves dividing the port authority's principal activities into separate autonomous operating units that are outsourced to private enterprises), liberalization (whereby statutory restrictions on competition are eliminated, thus allowing the 
private sectorto provide a full range of portservices), or outright sale of assetsor shares to the private sector.

Considering private capital only takes few proportion of domestic capital, for simplicity, the paper considers a port with two kinds of capital nature terminals, say terminals 1 and 2, which are state investment and foreign investment respectively, the capacity of which are perfectly substitutable expressing by $s_{1}$ and $s_{2}$.

There is a continuum of shippers of the same type with a utility function of:

$$
U\left(q_{1}, q_{2}\right)=\alpha_{1} q_{1}+\alpha_{2} q_{2}-\frac{\beta_{1} q_{1}^{2}+2 \gamma q_{1} q_{2}+\beta_{2} q_{2}^{2}}{2}
$$

where $q_{1}\left(q_{2}\right)$ is the demand of terminal 1 (2). The values of $\alpha_{i}$ and $\beta_{i}$ for $i=1,2$ are positive. This paper assume that two terminals are perfectly substitutable, i.e., $\alpha_{1}=\alpha_{2}=\alpha$ and $\beta_{1}=\beta_{2}=\gamma=\beta$. Following Singh and Vives [16], the total shipper (consumer) surplus is $\mathrm{U}\left(\mathrm{q}_{1}, \mathrm{q}_{2}\right)-\mathrm{p}_{1} \mathrm{q}_{1}-\mathrm{p}_{2} \mathrm{q}_{2}$, where $p_{1}\left(p_{2}\right)$ is the total cost of a shipper using terminal $1(2)$.

The total cost faced by a shipper takes the form as follows:

$$
\mathrm{p}=\mathrm{f}+\mathrm{t} \cdot \frac{\mathrm{q}}{\mathrm{s}}+\mathrm{e}
$$

where $\mathrm{f}$ is the terminal charge, $\mathrm{q}$ is the demand absorbed by the terminal, $\mathrm{t}$ is the parameter of cargo waiting cost in the terminal, where $\mathrm{s}$ is the overall designed capacity of the port, $r \in[0,1]$ indicates the proportion of state-owned capital investment, e is carbon emission tax per cargo unit. Furthermore, the shippers are assumed to have perfect information about the charges of the two terminals, denoted by $\mathrm{f}_{1}$ and $\mathrm{f}_{2}$.

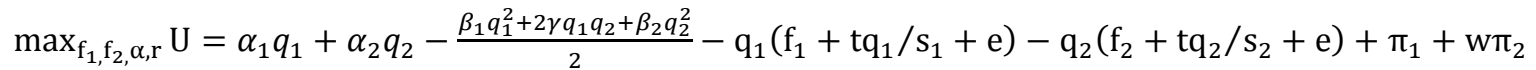

where $w \in[0,1]$ is the weight of foreign investment's operation profit in the objective of government.

Next this papersummarizes the optimal capital structure to maximize the social welfare. By taking the derivative of Eq. (9) and setting it equal to zero to get the condition:

$$
\begin{array}{r}
\alpha_{1} \frac{\partial q_{1}}{\partial \mathrm{r}}+\alpha_{2} \frac{\partial q_{2}}{\partial \mathrm{r}}-\left(\beta_{1} q_{1} \frac{\partial q_{1}}{\partial \mathrm{r}}+\gamma q_{2} \frac{\partial q_{1}}{\partial \mathrm{r}}+\gamma q_{1} \frac{\partial q_{2}}{\partial \mathrm{r}}+\beta_{2} q_{2} \frac{\partial q_{2}}{\partial \mathrm{r}}\right)-\left(\mathrm{f}_{1}+\mathrm{tq}_{1} / \mathrm{s}_{1}+\mathrm{e}\right) \frac{\partial q_{1}}{\partial \mathrm{r}}-\mathrm{q}_{1} \frac{\mathrm{t}}{\mathrm{s}}\left(\frac{\frac{\partial q_{1}}{\partial \mathrm{r}}}{\mathrm{r}}-\frac{q_{1}}{\mathrm{r}^{2}}\right) \\
-\left(\mathrm{f}_{2}+\mathrm{tq}_{2} / \mathrm{s}_{2}+\mathrm{e}\right) \frac{\partial q_{2}}{\partial \mathrm{r}}-\mathrm{q}_{2} \frac{\mathrm{t}}{\mathrm{s}}\left(\frac{\frac{\partial q_{2}}{\partial \mathrm{r}}}{1-\mathrm{r}}-\frac{q_{2}}{(1-r)^{2}}\right)+f_{1} \frac{\partial q_{1}}{\partial \mathrm{r}}-\theta \frac{\partial q_{1}}{\partial \mathrm{r}}-2 \tau \mathrm{r} s^{2}+\mathrm{w}\left(f_{2} \frac{\partial q_{2}}{\partial \mathrm{r}}-\theta \frac{\partial q_{2}}{\partial \mathrm{r}}+2 \tau(1-\mathrm{r}) s^{2}\right)
\end{array}
$$

where:

$$
\begin{aligned}
& \frac{\partial q_{1}}{\partial \mathrm{r}}=-\frac{[\beta \mathrm{s}(1-2 \mathrm{r})-\mathrm{t}] \mathrm{s}}{\mathrm{t}(\beta \mathrm{s}+\mathrm{t})} \mathrm{f}_{1}+\frac{\beta s^{2}(1-2 \mathrm{r})}{\mathrm{t}(\beta \mathrm{s}+\mathrm{t})} \mathrm{f}_{2}-\frac{(\alpha-\mathrm{e}) \mathrm{s}}{\beta \mathrm{s}+\mathrm{t}} \\
& \frac{\partial q_{2}}{\partial \mathrm{r}}=-\frac{[\beta \mathrm{s}(1-2 \mathrm{r})-\mathrm{t}] \mathrm{s}}{\mathrm{t}(\beta \mathrm{s}+\mathrm{t})} \mathrm{f}_{2}+\frac{\beta s^{2}(1-2 \mathrm{r})}{\mathrm{t}(\beta \mathrm{s}+\mathrm{t})} \mathrm{f}_{1}-\frac{(\alpha-\mathrm{e}) \mathrm{s}}{\beta \mathrm{s}+\mathrm{t}}
\end{aligned}
$$

\section{Numerical case}

\subsection{Geographical Location of the Container Port Area in Shanghai}

Port of Shanghai is situated at the middle of the 18000 km-long Chinese coastline, where the Yangtze River, known as "the Golden Waterway", flows into the sea. It is the leading port in the T-shaped waterway network composed by the Yangtze River and the coastline, and is also China's largest comprehensive port and one of the country's most important gateways for foreign trade, the annual import and export trade through Shanghai, in terms of value, accounts for a quarter of China's total foreign trade.

There are two major container port areas in Shanghai. One is Waigaoqiao Container Port Area, including Waigaoqiao container terminals of Phase 1, Phase $2 \& 3$, Phase 4, Phase 5 as well as Phase 6. The other is Yangshan Deepwater Port Area, including container terminals of Phase $1 \& 2$, Phase 3 
and Phase 4. With its favorable geographical location and unique strategic positioning, two major container port areas has been playing a vital part in building Shanghai into an international shipping center and contributing towards the flourishing economy in Shanghai and Yangtze River Delta through concerted efforts, promoting Shanghai Port to be one of the busiest ports in the world, the geographical location of which is shown in Fig. 1.

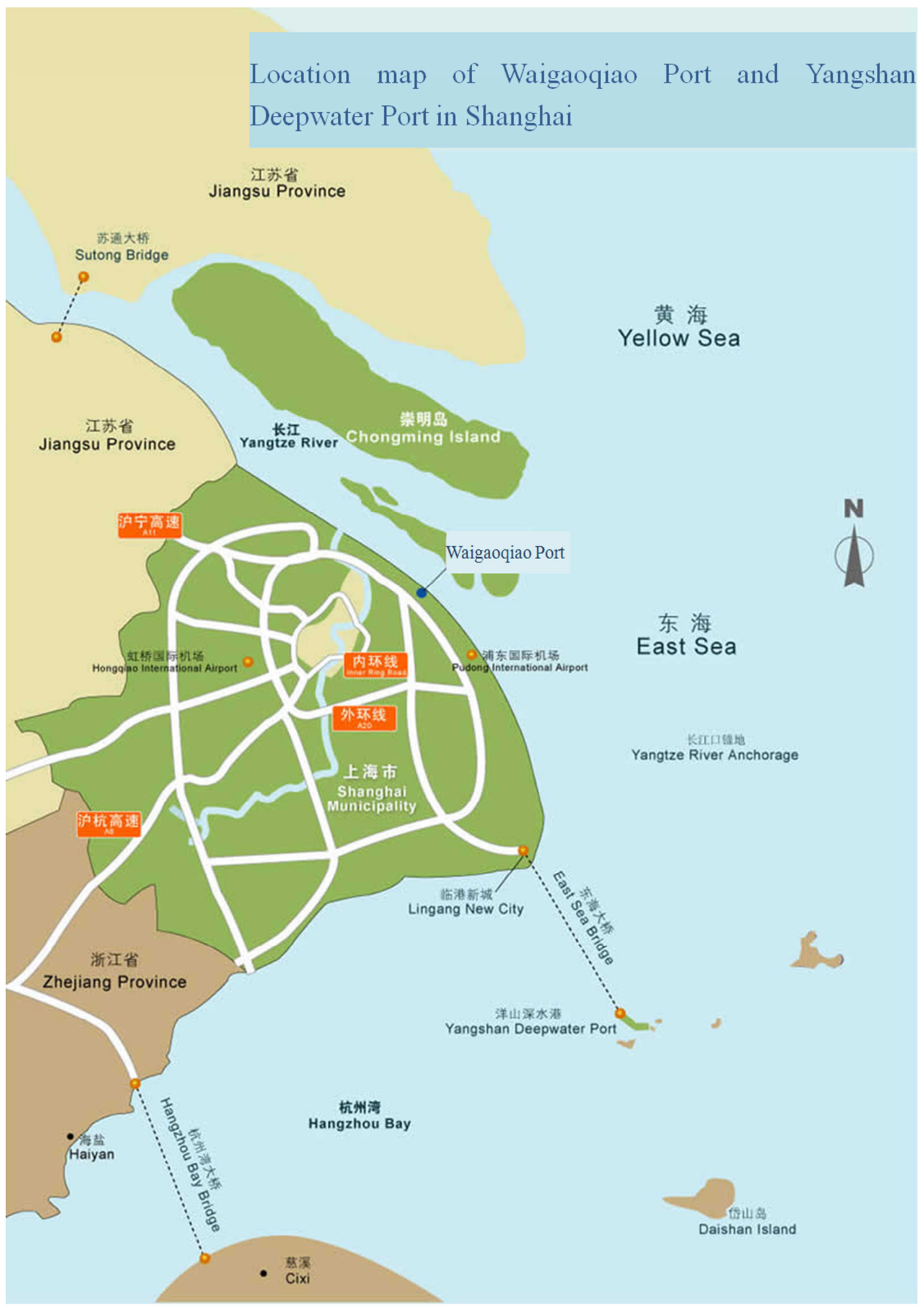

Figure 1. Location map of Waigaoqiao Port Area and Yangshan Deepwater Port Area in Shanghai. 


\subsection{Background Investment of the Container Port Area in Shanghai}

The administrative and investment structures of the principal container port area of a port provide an aspect of the competition and cooperation. Shanghai Municipal Transport Commission represents local government of Shanghai, the inspection and approval items of port shoreline utilization, permission of engineering of port facility, license of port operation, management of ships engaged in international voyages etc.

Shanghai International Port (Group) Co., Ltd. (SIPG) is the largest port of joint-stock enterprises in China, Shanghai State-owned Assets Supervision and Administration Commission (SSASAC) is the largest shareholder of SIPG, directly holds $44.23 \%$. SIPG has been fully developing the four industries of container, bulk cargo, port service and port logistics, as the former of Shanghai Port Authority, implementing the strategy of Yangtze River, Northeast Asia and Internationalization, particularly participating in investment, construction and operation management of the Yangshan Deepwater Port Area.

In addition to the main shareholder of SIPG, other shareholders of the container port area include: Hutchison Port Holdings Group (HPH), A.P. Moller-Maersk Group (APMT), COSCO Pacific Investment Co. Ltd and COSCO Port Ltd, which are given in Table 1.

Table 1. Background investment of the container terminals in port area.

\begin{tabular}{ll}
\hline $\begin{array}{l}\text { The phase of major } \\
\text { container port area }\end{array}$ & $\begin{array}{l}\text { The state-owned capital and foreign } \\
\text { investment }\end{array}$ \\
\hline Waigaoqiao Phase 1 & $\begin{array}{l}\text { SIPG:40\%, HPH:30\%, COSCO Pacific } \\
\text { Investment Co. Ltd:20\%, COSCO } \\
\text { PortLtd: } 10 \%\end{array}$ \\
Waigaoqiao Phase 2 \& 3 & SIPG: $100 \%$ \\
Waigaoqiao Phase 4 & SIPG:51\%, APMT:49\% \\
Waigaoqiao Phase 5 & SIPG:50\%, HPH:50\% \\
Yangshan Phase 1 \& 2 & SIPG:49\%, SCT:51\% \\
\hline
\end{tabular}

\subsection{The Value About the Parameters of the Case}

\subsubsection{The Potential Demand}

The potential demand of the port depends on its geological location, quay depth, operation efficiency and value-added service, such as on-time delivery, shipment frequency, trip tracking, vehicle monitoring, compensation commitment as well as extending financial service.

Therefore, according to the total container throughput of Yangtze River Delta in 2015, the demand scale of Shanghai port is assumed to be $\alpha=75.01$ million TEUs.

\subsubsection{The Inverse of Price Elasticity}

Although the port's demand is a derived demand and it is inelastic to its cost, it still could be affected by the generalized price. Some studies have determined the value of the sensitivity parameter, Luo et al. [17] get the price sensitivities of Shenzhen Port and Hong Kong Port as 0.15 million TEUs $/ \$$ and 0.1 million TEUs $/ \$$ respectively. As the inverse of price elasticity, this papertakes exchange rate and operational practice into consideration and calculates the value in our model is $\beta=41.87 \mathrm{RMB} /$ million TEUs.

\subsubsection{The Waiting Cost}

In perspective of the shipper, the waiting cost in Shanghai port should include the time cost of containerized cargo and the storage charge. This papercalculates the value of the parameter $\mathrm{t}=270.25 \mathrm{RMB} / \mathrm{TEU}$.

\subsubsection{The Designed Capacity}

Combined the background information, the values of designed capacity are $s=22.65, s_{1}=14.95, s_{2}=7.70$ (million TEUs).

\subsubsection{The Lump-Sum Rate}

The lump-sum rate of 20' common heavy container in Port of Shanghai is $\mathrm{f}=583.5 \mathrm{RMB}$.

\subsubsection{Other Parameters}

The values of others parameters are $e=1.25, w=0.5$, $\theta=148.09, \tau=0.03$.

\subsection{Illustration Analysis of the Case}

This paper performs an illustration analysis to gain further managerial insights about optimal state-owned investment of container capacity in Shanghai Port, some interesting results are shown as following:

Table 2. The investment optimization of container capacity in Shanghai.

\begin{tabular}{lll}
\hline $\begin{array}{l}\text { State-owned capital } \\
\text { held }(\%)\end{array}$ & $\begin{array}{l}\text { Container port area } \\
\text { charge } \mathbf{f}_{\mathbf{1}}(\mathbf{R M B})\end{array}$ & $\begin{array}{l}\text { Container port area } \\
\text { charge } \mathbf{f}_{\mathbf{2}}(\mathbf{R M B})\end{array}$ \\
\hline 37.30 & 583.5 & 583.5 \\
$37.30 *(1-0.32 \%)$ & 583.5 & $583.5 *(1+5 \%)$ \\
$37.30 *(1-0.64 \%)$ & 583.5 & $583.5 *(1+10 \%)$ \\
$37.30 *(1-0.97 \%)$ & 583.5 & $583.5 *(1+15 \%)$ \\
$37.30 *(1-1.26 \%)$ & 583.5 & $583.5 *(1+20 \%)$ \\
\hline
\end{tabular}

First up, taking the current charge level into consideration, there is significant potential space in the investment optimization of container capacity in Shanghai, decreasing the state-owned investment from $65.60 \%$ to $37.30 \%$.

Secondly, according to the deregulation of China's Ministry of Transport, the container joint venture has the right to pricing its stevedoring rate with $20 \%$ float ratio of up and down, while the other container company should comply with the container stevedoring rates modified in 2001. The more charge of the foreign investment container port area increased, the lower proportion of the state-owned investment, that is the foreign investment container port area raising $20 \%$ of its charge, the state-owned investment further dropping from $37.30 \%$ to $36.83 \%$.

\section{Conclusion}

China was relatively slow in allowing foreign investment into its port sector. Before the 1980s, Chinese port investments were $100 \%$ on the account of the state, especially the national fiscal budget. With deregulation of restrictions on foreign 
investment, container port investments are including the state investment, bank loans, self-raised funds, foreign investment and IPO and so on.

The paper focuses on optimization of state-owned capital and foreign investment with the basics of the model proposed, putting forth some conclusions and policy recommendations through conducting numerical illustration of the Shanghai case. Even taking the current charge level into consideration, there is significant potential space in the investment optimization of container capacity in Shanghai. Moreover, the more charge of the container port area related foreign investment decreased, the lower proportion of the state-owned investment capacity.

\section{Acknowledgements}

This research was financially supported by Shanghai Fundamental Research Project (15590501800).

The author expresses his gratitude to the editor, and anonymous reviewers for their constructive and insightful comments on this paper.

\section{References}

[1] K. Cullinane, D. W. Song and R. Gray, "A stochastic frontier model of the efficiency of major container terminals in Asia: assessing the influence of administrative and ownership structures,” Transp. Res. Part A, vol. 8, 2002, pp. 743-762.

[2] J. Tongzon and W. Heng, "Port privatization, efficiency and competitiveness: Some empirical evidence from container ports (terminals)," Transp. Res. Part A, vol. 39, 2005, pp. 405-424.

[3] S. X. H. Gong, K. Cullinane and M. Firth, "The impact of airport and seaport privatization on efficiency and performance: A review of the international evidence and implications for developing countries," Transport Policy, vol. 24, 2012, pp. 37-47.

[4] P. C. Millán, X. L. Fernández, S. Hidalgo and M. A. Pesquera, "Public regulation and technical efficiency in the Spanish Port Authorities: 1986-2012,’Transport Policy, vol. 47, 2016, pp. 139-148.

[5] J. I. C. Manzano, M. C. Nuño, X. Fageda and M. G. Aregall,
"Evaluating the effects of the latest change in Spanish port legislation: Another "turn of the screw" in port reform," Case Studies on Transport Policy, vol. 4, 2016, pp. 170-177.

[6] M. Allahviranloo and S. Afandizadeh, "Investment optimization on port's development by fuzzy integer programming," Eur J Oper Res, vol. 186, 2008, pp. 423-434.

[7] J. H. Lin, B. H. Gao and C. R. Zhang, "Simulation-based investment planning for Humen Port," Simulation Modelling Practice and Theory, vol. 40, 2014, pp. 161-175.

[8] N. L. Ioannis, B. R. J. James and B. S. Jason, "Port Investment Strategies under Uncertainty: The Case of a Southeast Asian Multipurpose Port," The Asian Journal of Shipping and Logistics, vol. 30, 2014, pp. 299-319.

[9] Y. B. Xiao, X. W. Fu, A. K. Y. Ng and A. M. Zhang, "Port investments on coastal and marine disasters prevention: Economic modeling and implications," Transp. Res. Part B, vol. 78, 2015, pp. 202-221.

[10] Y. J. Seo and J. S. Park, "The estimation of minimum efficient scale of the port industry," Transport Policy, vol. 49, 2016, pp. $168-175$.

[11] W. Y. Yap and J. S. L. Lam, "Competition dynamics between container ports in East Asia," Transp. Res. Part A, vol. 40, 2006, pp. 35-51.

[12] G. T. Yeo, M. Roe and J. Dinwoodie, "Evaluating the competitiveness of container ports in Korea and China," Transp. Res. Part A, vol. 42, 2008, pp. 910-921.

[13] S. Y. Zheng and R. R. Negenborn, "Centralization or decentralization: A comparative analysis of port regulation modes,” Transp. Res. Part E, vol. 69, 2014, pp. 21-40.

[14] L. Song and M. V. Geenhuizen, "Port infrastructure investment and regional economic growth in China: Panel evidence in port regions and provinces," Transport Policy, vol. 36, 2014, pp. 173-183.

[15] J. H. Zhang, "Quasi-landlord port financing in China: Features, practice and a contract theory analysis," Transp. Res. Part A, vol. 89,2016 , pp. 73-88.

[16] N. Singh and X. Vives, "Price and quantity competition in a differentiated duopoly," Rand J. Econ, vol. 15, 1984, pp. 546-554.

[17] M. Luo, L. Liu and F. Gao, "Post-entry container port capacity expansion," Transp. Res. Part B, vol. 46, 2012, pp. 120-138. 